\title{
The Empire Writes Back (to Michael Ignatieff)
}

Rahul Rao

This article critiques the re-legitimisation of empire evident in recent writing by Michael Ignatieff. It begins by locating his work within the larger debate on empire emerging today. Focusing first on Ignatieff's more general comments on empire, it suggests that his defensive case for empire is misleading: it ignores the extent to which the circumstances allegedly necessitating 'new' empire are themselves a consequence of older empire, and indeed older US empire. Focusing next on Ignatieff's largely consequentialist case for the 2003 attack on Iraq, it argues that the 'success' of the imperial project - to the extent that this requires the cooperation of Iraqis - will depend crucially on the motives of the imperialists. Without engaging directly with Ignatieff's work, the final section addresses some of the questions that the foregoing critique may have raised. In particular, it examines critically the claim that empires are legitimised by the public goods they provide.

There has been a tremendous renewal of interest in 'empire' as a concept relevant to the understanding of contemporary international relations. This is an entirely welcome development, if only because a term that has long been an epithet deployed by the left and denied by the right seems to be regaining the status of an analytical category enabling us to describe the way power is actually exercised in the world today. Nevertheless, a worrying aspect of this new scholarship-especially for a reader from the postcolonial developing world-is the insidious return of normative defences of empire. This trend is particularly evident in Michael Ignatieff's recent musings on empire, which constitute the focus of this article. I begin by locating Ignatieff's work in the context of the larger debate on empire that is emerging today. In the following two sections I focus, first, on his more general comments on empire and

Thanks for comments are due to Andrew Hurrell, Henry Shue, James Paul, Stamatia Piper, Simon Archer and Elizabeth Angell. I am also grateful to the editors and anonymous reviewers of Millennium, for their very helpful suggestions. Apologies for the somewhat presumptuous title-I can do no better than to echo Arundhati Roy, in speaking 'as a [relatively privileged] subject of the American Empire . . . as a slave who presumes to criticise [his] king'. 
second, on his justification of the 2003 attack on Iraq as empire-in-action. I hope to offer a critique that brings to light the myths and blind spots on which his re-legitimisation of empire depends. In the concluding section I do not engage directly with Ignatieff's work, but attempt to address some of the questions that my own critique may have raised. In particular, I am keen to address the oft-repeated assertion that empires are legitimised by the public goods that they provide.

\section{Locating Ignatieff}

Although the re-legitimisation of empire has been a long time coming, ${ }^{1}$ the debate has acquired a new urgency in the wake of the terrorist attacks of September 11, 2001. Two broad justifications for the 'return' of empire are typically advanced in the recent literature. The first is that dysfunctional states, by serving as a locus for terrorism, drug trafficking, 'weapons of mass destruction-related programme activities' and a host of other unsavoury endeavours, pose a threat to order and stability the world over. This gives powerful states no choice but to impose more decent forms of governance on them, by force if necessary. As Sebastian Mallaby puts it, 'the logic of neo-imperialism is too compelling . . . to resist' in such circumstances. ${ }^{2}$ From the point of view of the imperial power, this is a defensive and self-regarding justification: empire is justified as being necessary in the security interests of the metropolis. ${ }^{3}$ The flip side of this argument provides a second justification for empire: empire is good for the periphery because it brings good governance to 'rogue' or 'failed' states, thereby ensuring greater respect for the human rights of their inhabitants. This is an other-regarding justification for empire, one that many see as being the contemporary variant of the mission civilisatrice.

Although commentators typically advance a blend of both justifications, ${ }^{4}$ variations of emphasis are evident. For Ignatieff, it is the other-regarding justifications that clinch the argument for the recent

1. See Frank Furedi, The New Ideology of Imperialism: Renewing the Moral Imperative (Boulder: Pluto Press, 1994).

2. Sebastian Mallaby, 'The Reluctant Imperialist: Terrorism, Failed States, and the Case for American Empire', Foreign Affairs 81, no. 2 (2002): 6.

3. See also Max Boot, 'The Case for American Empire', The Weekly Standard 7, no. 5 (2001), www.weeklystandard.com.

4. See Robert Kagan, 'The Benevolent Empire', Foreign Policy 111 (Summer 1998): 24-35; Richard N. Haass, 'Imperial America', paper at the Atlanta Conference, Puerto Rico (November 11, 2000), http://www.brookings.edu/ dybdocroot/views/articles/haass/2000imperial.htm; Robert D. Kaplan, Warrior 
attack on Iraq (and empire more broadly). In his latest piece (which is, incidentally, an attempt to seriously qualify many of his earlier Iraqspecific claims in light of the deteriorating situation in that country), he says,

While I thought the case for preventive war [based on selfregarding justifications] was strong, it wasn't decisive. It was still possible to argue that the threat was not imminent and that the risks of combat were too great. What tipped me in favour of taking these risks was the belief that Hussein ran an especially odious regime and that war offered the only real chance of overthrowing him. ${ }^{5}$

I want to focus here on Ignatieff's other-regarding case for empire. In doing this, I concur with Eric Hobsbawm's judgment that the 'imperialism of human rights' advocated by 'a minority of influential intellectuals, including Michael Ignatieff in the US' is 'more dangerous' than the selfinterested arguments for empire advanced by the right, because of the veneer of legitimacy that it gives this project. ${ }^{6}$ The liberal, human rightsbased case for a revival of empire is powerfully reinforced by the moral rehabilitation of old empire, for which no one has done more in recent times than Niall Ferguson. His magnum opus Empire: How Britain Made the Modern World, makes for fascinating reading, particularly in his listing of what he takes to be the credit side of British imperial achievement.?

Politics: Why Leadership Demands a Pagan Ethos (New York: Random House, 2002), 147; Dinesh D'Souza, 'In praise of American empire', The Christian Science Monitor (April 26, 2002).

5. Michael Ignatieff, 'The Way We Live Now: The Year of Living Dangerously', The New York Times Magazine (March 14, 2004), www.nytimes.com.

6. Eric Hobsbawm, 'After the Winning of the War-United States: wider still and wider', Le Monde diplomatique (June 2003), http://mondediplo.com/ 2003/06/02hobsbawm.

7. Niall Ferguson, Empire: How Britain Made the Modern World (London: Penguin, 2003), xxv. These are: (i) the triumph of capitalism as the optimal system of economic organisation; (ii) the Anglicisation of North America and Australasia; (iii) the internationalisation of the English language; (iv) the enduring influence of the Protestant version of Christianity; and (v) the survival of parliamentary institutions. No consideration is given to the fact that the triumph of capitalism' often involved resource plunder and the destruction of local manufacturing capacity, or that the 'Anglicisation of North America and Australasia' were achieved at the cost of genocide of the indigenous inhabitants of those continents, or that there is nothing self-evidently superior about Anglicisation, English and Protestantism (at least to the vast majority of humanity who share few or none of these identities). 
Further reinforcement was provided at a recent conference on 'failing states and benevolent empires', where a leading academic noted with satisfaction that developing countries had finally stopped blaming colonialism for all their problems and started taking responsibility for their own development, or lack thereof. ${ }^{8}$ When western academics express impatience at imputations of historical responsibility for colonialism, they in effect arbitrarily impose a statute of limitation on discussions of old empire, even as others in the academy-like Ignatieff-open new chapters in this evolving story. The convergence of this whitewashing of old imperialism, limitation of its moral responsibility, and advocacy of new imperialism has fuelled a profoundly disturbing renewal of enthusiasm for empire in the western academy today.

Nevertheless, even within the western academy the case for empire has been fiercely contested. A number of commentators have advanced self-regarding arguments against empire, emphasising the dangers that the imperial project poses to the metropolis. These range from Chalmers Johnson's astonishingly prescient warning of 'blowback', ${ }^{9}$ to traditional Realist predictions of self-encirclement by counter-balancing coalitions of hostile powers as well as the possibility of imperial overstretch. ${ }^{10}$ Johnson also laments the implications of the imperial project for political culture in the metropolis: enhanced militarism, loss of democracy and constitutional rights, and an increased role for propaganda. ${ }^{11}$ Other voices have drawn attention to the profound ironies inherent in otherregarding justifications for empire: the claim of empire to bring 'rule of law' when it is itself a violation of law, the challenge of simultaneously presenting the imperial project as a philanthropic mission (to an international audience) and as being in the national interest (to a domestic audience) ${ }^{12}$ as well as the very oxymoronic character of 'liberal imperialism'.$^{13}$

8. The Boston, Melbourne, Oxford Conversazione 2003, 'Making States Work: Failing States and Benevolent Empires', University of Oxford (September 4-6, 2003).

9. Chalmers Johnson, Blowback: The Costs and Consequences of American Empire (London: Time Warner, 2002).

10. G. John Ikenberry, 'America's Imperial Ambition', Foreign Affairs 81, no. 5 (2002): 44-60; Ivan Eland, 'The Empire Strikes Out: The "New Imperialism" and Its Fatal Flaws', Policy Analysis, no. 459 (2002).

11. Chalmers Johnson, The Sorrows of Empire: Militarism, Secrecy, and the End of the Republic (New York: Metropolitan Books, 2004). For a combination of the above arguments see Clyde Prestowitz, Rogue Nation: American Unilateralism and the Failure of Good Intentions (New York: Basic Books, 2003).

12. Pratap Bhanu Mehta, 'Empire and Moral Identity', Ethics and International Affairs 17, no. 2 (2003): 49-62.

13. Edward Rhodes, 'The Imperial Logic of Bush's Liberal Agenda', Survival 
Finally, there is a growing body of work that employs the category 'empire' in an ostensibly value-neutral sense (although subtle normative slants are evident), highlighting the different sorts of analytical purchase that this enables. For Barkawi and Laffey, the concept 'offers a way out of the "territorial trap" set by Westphalia and alerts us to a range of phenomena occluded by IR's central categories' (such as the Realist fiction of an anarchical international system). ${ }^{14}$ For Michael Cox, it effectively dispels the myth of US exceptionalism and enables comparisons between the US and other great powers in history. ${ }^{15}$ For Martin Shaw, it forces us to acknowledge the post-imperial character of the West and the quasi-imperial character of politics in much of the nonWestern world (a useful insight that he then goes on to employ very problematically, as I later suggest). ${ }^{16}$ Notwithstanding the analytical utility of this literature, it has its own blind spots. With the possible exception of Barkawi and Laffey, these writers are not very interested in the peripheries of imperial systems and more specifically with how empire looks from below. Among other things, I attempt to explore the 'points of impact' where imperial powers and local collaborators-or resistors-interact, for it is here that the viability of imperial arrangements will ultimately be revealed. ${ }^{17}$

\section{Ignatieff on Empire}

It is worth spelling out why Ignatieff's use of 'empire' is more than simply descriptive or analytical. His book Empire Lite begins with an introductory caveat seeking to characterise the project as value-neutral description ('I am not interested in using the world imperial as an epithet. I would prefer to use it as a description and to explore how American imperial power is actually exercised $\left.{ }^{\prime 18}\right)$. Nevertheless, prescription is frequently smuggled in: 'nobody likes empires, but there are some problems for which there are only imperial solutions' ${ }^{\prime 19}$ and elsewhere-

45, no. 1 (2003): 131-154. For a critique of both self- and other-regarding arguments for empire see Jedediah Purdy, 'Liberal Empire: Assessing the Arguments', Ethics and International Affairs 17, no. 2 (2003): 35-47.

14. Tarak Barkawi \& Mark Laffey, 'Retrieving the Imperial: Empire and International Relations', Millennium: Journal of International Studies 31, no. 1 (2002): 109.

15. Michael Cox, 'The Empire's Back in Town: Or America's Imperial Temptation -Again', Millennium: Journal of International Studies 32, no. 1 (2003): 23.

16. Martin Shaw, 'Post-Imperial and Quasi-Imperial: State and Empire in the Global Era', Millennium: Journal of International Studies 31, no. 2 (2002): 327-336.

17. Stephen Howe, 'American Empire: the history and future of an idea', http:/ / www.opendemocracy.net/debates/article-6-27-1279.jsp\#

18. Michael Ignatieff, Empire Lite (London: Vintage, 2003), 3. 
'imperialism doesn't stop being necessary just because it becomes politically incorrect' ${ }^{20}$ Indeed 'the key question', as he sees it, 'is whether empire lite is heavy enough to get the job done'..$^{21}$

The framing of this question is noteworthy, particularly for the way it leaves undisturbed the assumption that 'empire' is the way 'to get the job done'. All that remains to quibble over is how coercive it needs to be in order to do so. 'The job', as Ignatieff goes on to explain, involves dealing with the threats and insecurities generated by 'failed', 'failing' or 'rogue' states. ${ }^{22}$ 'Nations sometimes fail, and when they do only outside help - imperial power - can get them back on their feet'..$^{23}$ Note also how, for Ignatieff, 'imperial power' seems to be the only form that 'outside help' can take. Perhaps we should not be surprised at the essential synonymity of these ideas from the perspective of the rulers, but Ignatieff also claims to speak for the ruled: thus, 'Afghans . . . understand the difficult truth that their best hope for freedom lies in a temporary experience of imperial rule' ${ }^{24}$ (For a sense of how little divides, in practice and rhetoric, self-regarding from other-regarding justification or conservative from liberal, one has only to listen to Max Boot: 'Afghanistan and other troubled lands cry out for the sort of enlightened foreign administration once provided by self-confident Englishmen in jodhpurs and pith helmets'.25) Troubled lands in the postcolonial world have been crying out for many forms of 'outside help ${ }^{26}$ - fairer terms of trade, technology transfer, debt forgiveness, more aid, to provide just a sample - but one is hard pressed to find voices that enjoy any sort of legitimacy in the Third World, expressing 'empire nostalgia'.

19. Ibid., 11.

20. Ibid., 106.

21. Ibid., 3 .

22. Ignatieff does not distinguish very clearly between these quite distinct phenomena. It is now commonly accepted that failed states are characterised by a collapse of governmental authority and a resulting state of anarchy (e.g. Somalia in 1991-92). In 'rogue' states there is usually a functioning government, which is perceived as behaving aggressively in its external relations with other states and/or abusing the human rights of its citizens internally. There is a possible (but by no means inevitable) overlap between the two, and it seems reasonable to suppose that they demand distinct policy approaches.

23. Ignatieff, Empire Lite, 106.

24. Ibid., 107.

25. Boot, 'The Case for American Empire'.

26. For an excellent survey of these demands and the reactions they elicited at a time when they were given possibly their most institutionalised expression, see Robert W. Cox, 'Ideologies and the New International Economic Order: reflections on some recent literature', International Organisation 33, no. 2 (1979): 257-302. 
Closer attention to the causes of state failure reveals that many of these had their roots in an older era of empire. The risks of state failure are greatest in those former colonial possessions in which the processes of state-and nation-building have not sufficiently advanced. Mohammed Ayoob reminds us that most developing countries have had to telescope these dual tasks into a combined and drastically shortened process, without the luxury of time and agency that western European states have enjoyed. Further, they have had to do so under extremely difficult conditions: having inherited arbitrary boundaries and ethnically heterogeneous populations from their imperial predecessors, they suffer from a lack of internal cohesiveness and state legitimacy. This has condemned many of them to a postcolonial lifetime of civil war and secessionist strife- usually precursors to complete state failure. ${ }^{27}$

The egregious exploits of the corrupt, venal elites that rule many of these states are frequently cited as justification for the revival of empire. Yet only by looking at the more critical-historical scholarship of Alexander Wendt and Michael Barnett do we get a sense of the extent to which these elites are themselves creatures of older 'benevolent' empire. ${ }^{28}$ Wendt and Barnett explain how colonial patterns of skewed economic development resulted in a situation of disarticulation or dualism, whereby colonial economies tended to spawn a modern sector (usually closely integrated with the metropolitan and world economies) in addition to the existing traditional sector. Colonial governments came to rely heavily on native elites associated with the modern sector for the purposes of maintaining order and extracting revenue from the colony. This arrangement benefited native elites materially, and in doing so bound them closely to the metropolitan state while breaking down their ties to the mass of the native population. In most cases, decolonisation merely handed over the reins of power to local elites, who then consolidated their internal security position vis-à-vis the 'threat' posed by the masses by continuing to rely on external economic and political ties. In the situation of 'informal empire' ${ }^{29}$ that characterised the Cold War, these ties took the form of 'security assistance' provided by the superpowers to Third World elites in return for their cooperation in the pursuit of Cold War objectives. The illegitimate regimes inherited from

27. Mohammed Ayoob, The Third World Security Predicament (London: Lynne Rienner, 1995).

28. Alexander Wendt and Michael Barnett, 'Dependent State formation and Third World militarisation', Review of International Studies 19, no. 4 (1993): 321-347.

29. Wendt and Barnett define informal empire as a socially structured system of interaction among juridically sovereign states in which one, the 'dominant' state, has a significant degree of de facto political authority over the security policies of another 'subordinate' state. 
colonialism therefore reproduced themselves, with external patronage continuing to obviate the need for native elites to obtain the consent of the governed or to arrive at the sort of labour-capital compromises that characterise western welfare states.

To locate the roots of contemporary state failure in earlier eras of European and US empire is not to engage in some self-congratulatory blame game. Nor should it provide any measure of comfort to Third World elites, who, as the preceding account suggests, have proved only too willing to collude with metropolitan elites in their self-interest. Rather it is to affirm, in the words of Edward Said, 'the interdependence of various histories on one another, and the necessary interaction of contemporary societies with one another' ${ }^{\prime}{ }^{30}$ with a view to avoiding a repetition of the injustices of the past. To be fair, Ignatieff alludes to the idea of failing states as legacies of em-pires past, but the connections are left exceedingly vague and ill-defined:

Being an imperial power ... means carrying out imperial functions in places America has inherited from the failed empires of the $20^{\text {th }}$ century. ... America has inherited this crisis of self-determination from the empires of the past. ... America has inherited a world scarred not just by the failures of empires past but also by the failure of nationalist movements to create and secure free states. ${ }^{31}$

More problematically, Ignatieff sees the failures of past empires and nationalist movements not as reason to adopt fundamentally new approaches to the resulting problems, but rather to revive the notion of imperial rule. This view is tantamount to arguing that crises of state failure are a result, not of too much imperialism, but too little.

This nostalgic view of empire is surprisingly widely held. Robert Jackson, for example, argues that hasty and premature decolonisation was more detrimental to the well-being of Third World states than the colonial encounter itself. ${ }^{32}$ Contrasting the different developmental trajectories of the 'white' dominions and colonies in the British empire, Ferguson says: 'That [the British empire] didn't deliver Canadian-style growth rates in India isn't explicable in terms of ruthless British exploitation. It's explicable in that there wasn't quite enough

30. Edward Said, Culture and Imperialism (London: Vintage, 1994), 43.

31. Michael Ignatieff, 'The Burden', The New York Times Magazine (January 5, 2003): 24, 53, 54.

32. Robert H. Jackson, Quasi-States: Sovereignty, International Relations, and the Third World (Cambridge: Cambridge University Press, 1996), 198-202. 
imperialism: the British didn't do quite enough to achieve that kind of growth' ${ }^{33}$ (But wasn't 'doing enough' in Canada and the other dominions premised on ruthless exploitation of the indigenous inhabitants?) The 'not enough imperialism' thesis is argued forcefully by Max Boot in his discussion of US intervention in Hispaniola: 'The marines had tried hard to plant constitutional government but found that it would not take root in the inhospitable soil of Hispaniola. The only thing that could have kept a Trujillo or Duvalier from seizing power was renewed US intervention. ... [T] he only thing more unsavoury than US intervention, it turned out, was US non-intervention' ${ }^{34}$ And elsewhere in a discussion of Nicaragua, 'dictatorship [in Nicaragua] was indigenous; democracy was a foreign transplant that did not take, in part because America would not stick around long enough to cultivate it'. ${ }^{35}$

Thus, economic, political and military crises in the postcolonial Third World have begun to serve as a retrospective justification for imperialism. There is a virtual consensus among the above writers that the roots of these crises are to be found, not in the colonial, but in the nationalist era. (In saying 'both', Ignatieff is usefully ambiguous on this point.) But as Frank Furedi argues, this is the contested question and we cannot begin by assuming we know the answers. ${ }^{36}$ In this context, Jedediah Purdy usefully reminds us that the failure of many postcolonial regimes does not in itself mean that the preceding colonial rule was a good thing, whose passing was to be regretted. Nor, more pertinently, does such failure indicate that independence was inherently unviable for those countries. While those countries faced severe disadvantages apart from the Cold War, we will never know whether some might have done much better free of the proxy battles of those decades' ${ }^{37}$

33. Niall Ferguson, 'Empire: The Rise and Demise of the British World Order and Lessons for Global Power', Carnegie Council Books for Breakfast (September 16, 2003), http://www.carnegiecouncil.org/viewMedia.php/ prmID/1033.

34. Max Boot, The Savage Wars of Peace: Small Wars and the Rise of American Power (New York: Basic Books, 2002), 181. Contrast this with John F. Kennedy's own admission: 'There are three possibilities, in descending order of preference: a decent democratic regime, a continuation of the Trujillo regime, or a Castro regime. We ought to aim at the first, but we cant really renounce the second until we are sure we can avoid the third'. Cited in Abraham F. Lowenthal, 'The United States and Latin American Democracy: Learning from History', in Exporting Democracy: The United States and Latin America, ed. Abraham F. Lowenthal (Baltimore: The Johns Hopkins University Press, 1991), 388.

35. Boot, The Savage Wars of Peace, 251.

36. Furedi, The New Ideology of Imperialism, 100, 106.

37. Purdy, 'Liberal Empire', 39. For a contrary view arguing that colonialism was preferable to the situation of 'quasi-statehood' in which many postcolonial 
Paying attention to those proxy battles reminds us of how deeply the US (together with the former USSR) is implicated in the production of 'rogue' and 'failed' states-something we are likely to forget reading Ignatieff. ${ }^{38}$ In his work, the US is presented as the 'reluctant republic' that has had imperial responsibility thrust upon it. The myth of reluctance allows the imperialist project to present itself as a primarily defensive enterprise. By obscuring or discounting the material motives driving new empire, the notion that the US has asserted itself only under extreme duress and then always for the noblest purposes has become the master narrative explaining and justifying the US' exercise of global power. ${ }^{39}$ In this vein, Ignatieff frequently reiterates the theme of inheritance, as if the US-arguably the single most powerful actor in the international system since the end of the First World War-has exercised no agency in bringing about the state of affairs in which it now finds itself. In his latest article, Ignatieff has-to his credit-explicitly acknowledged that 'like Osama bin Laden, whom the US bankrolled through the 1980s, [Saddam] Hussein was a monster partly of America's making ${ }^{\prime}{ }^{40}$ One wonders, first, why these vital admissions have been so late in coming (these are not new facts that have emerged after the 2003 attack on Iraq); and second, why-if previously known-they did nothing to change his mind. Surely, to recognise that the imperial power itself bears significant responsibility for producing the circumstances that now occasion its intervention is to suggest that new empire is something of a protection racket. ${ }^{41}$

Finally, it is worth interrogating the central assumption running through Ignatieff's work: namely, that empire can put failing states back on their feet

states found themselves upon decolonisation, see Jackson, Quasi-States, 146151.

38. Wendt and Barnett describe how illegitimate governance structures created by colonialism and imperialism endured during the Cold War because the superpowers found it convenient to exploit them for the pursuit of their global objectives. See Wendt and Barnett, 'Dependent State formation and Third World militarisation'. For an account of how the Cold War frustrated challenges to the legacies of empire throughout the world also see Mark N. Katz, 'The Legacy of Empire in International Relations', Comparative Strategy 12 (1993): 365-383.

39. Andrew J. Bacevich, American Empire: The Realities and Consequences of U.S. Diplomacy (Cambridge: Harvard University Press, 2002), 8, 87.

40. Ignatieff, 'The Way We Live Now'; For a brief account of the CIA role in bringing the Ba'ath party to power in Iraq and the subsequent US arming of Saddam Hussein, see Johnson, The Sorrows of Empire, 223-224.

41. For an account of the state as protection racket, see V. Spike Peterson, 'Security and Sovereign States: What is at Stake in Taking Feminism Seriously?', in Gendered States: Feminist (Re)Visions of International Relations Theory (Boulder: Lynne Rienner, 1992), 49-54. 
by assisting in nation-building. Perhaps what he really means is statebuilding. ${ }^{42}$ Empires have certainly shown themselves to be capable of building states where there were none before, but can they build nations? To be sure, the vast majority of postcolonial nationalisms today owe their existence in some measure, however indirectly, to empire. The crystallisation of an Indian national identity, for example, was greatly facilitated by the establishment of a subcontinent-wide network of communication facilities (particularly railways and telegraph), the introduction of an elite link language (English) and the infusion of new concepts into political discourse, thanks to the initiation of western education. In this sense, empire may be said to have provided the hardware of nationalism. But the software of nationalism-a shared sense of grievance and resistance to the imperialist invaders as well as the historical and cultural resources that provided an endless stream of hoary, nationalist myths - developed in opposition to, or independently of, empire. ${ }^{43}$ Empire provided the foil against which nationalisms and nations were constructed. So while Ignatieff may be right to think that empire has a role to play in nation-building, this role may evolve-as it has done before-in ways that ultimately prove deeply subversive of the imperialist project.

If empires cannot impart a sense of national identity, except in the indirect and inadvertent way described above, perhaps they have a role to play in 'democracy promotion' - an endeavour in which the US has been engaged for decades, with less than encouraging results. ${ }^{44}$ While there are many examples of democratic regimes originating from an act of external imposition, ${ }^{45}$ successful democracy promotion 'assumes the prior existence of a well-defined nation-state in which no major problems of national identity remain pending. ${ }^{46}$ This factor might

42. For a classic instance of this sort of confusion, see Ignatieff, Empire Lite, 79: 'Terror can't be controlled unless order is built in the anarchic zones where terrorists find shelter. In Afghanistan, this means nation-building, creating a state strong enough to keep al-Qaeda from returning'.

43. For a piercing analysis of the tendency in much of the British literature on empire to minimise the role of anti-imperialist protest in the process of decolonisation and/or to portray nationalism as entirely a conscious creation of empire, see Furedi, The New Ideology of Imperialism, 10.

44. See the extremely sobering conclusions of Lowenthal, 'The United States and Latin American Democracy', 383: 'Recurrent efforts by the government of the United States to promote democracy in Latin America have rarely been successful, and then only in a narrow range of circumstances'.

45. Laurence Whitehead, 'Three International Dimensions of Democratisation', in The International Dimensions of Democratisation, ed. Laurence Whitehead (Oxford: Oxford University Press, 1999), 8-15.

46. Laurence Whitehead, 'The Imposition of Democracy', in Exporting Democracy: The United States and Latin America, ed. Abraham F. Lowenthal (Baltimore: The 
explain both the triumph of US efforts in Germany and Japan following the Second World War, as well as the essential irrelevance of those precedents to the current situation in the Middle East. As Anatol Lieven points out, with the exception of Iran, none of the states in this region 'is a truly national one, and their sense of real common national purpose is weak. Where state nationalism does exist, the Israeli-Palestinian conflict and US support for Israel mean it is hard to mobilise it on the side of the west $^{\prime}{ }^{47}$ To answer Ignatieff's initial question, then: if democracy promotion is unlikely to be successful without a pre-existing sense of national identity, and if empire can do little to precipitate such an identity (except in a thoroughly antagonistic way), it is difficult to see how empire-however heavy-can accomplish the task of putting failing states back on their feet.

\section{Ignatieff on Iraq}

In the debate on the 2003 war on Iraq, some liberal proponents of empire jumped onto a fundamentally neo-conservative bandwagon. That there are differences of agenda between these two groups is hardly a secret. Ignatieff himself is candid about the lack of humanitarian motivation among the neo-con warmongers, despite their frequent use of liberal rhetoric to justify the war: 'The Iraq intervention was the work of conservative radicals, who believed that the status quo in the Middle East was untenable-for strategic reasons, security reasons and economic reasons. They wanted intervention to bring about a revolution in American power in the entire region' ${ }^{48}$ Of late, he has been even more explicit on this point: 'I knew that the administration did not see freeing Iraq from tyranny as anything but a secondary objective'; and elsewhere, 'supporting the war meant supporting an administration whose motives I did not fully trust for the sake of consequences I believed in'. ${ }^{49}$

Notwithstanding his recognition of the wide gulf separating neoconservative motivations from his own, Ignatieff seems to believe in the eventual reconcilability of these very different objectives. Writing with evident approval of the neo-con master plan, he says that the new pillar of US interests in the Middle East would be 'a democratic Iraq, at peace with Israel, Turkey and Iran, harbouring no terrorists, pumping oil for the world economy at the right price and abjuring any nasty designs on

Johns Hopkins University Press, 1991), 356.

47. Anatol Lieven, 'Lessons for Bush's Mideast Vision', Financial Times (March 1, 2004).

48. Michael Ignatieff, 'Why Are We In Iraq? (And Liberia? And Afghanistan?)', The New York Times Magazine (September 7, 2003): 71.

49. Ignatieff, 'The Way We Live Now'. 
its neighbours'.$^{50}$ There is not even the barest acknowledgement of potential contradictions in this deep and intrusive agenda: far from pumping oil for the world economy at the 'right' price, a democratic Iraq might very well decide that it needed to extract maximum revenue from its natural resources, or that it ought to strongly support Palestinian selfdetermination..$^{51}$ The historical record suggests that US democracy promotion efforts have often floundered precisely on this unwarranted assumption that all 'good' things (free markets, free peoples) go together. Where democracy promotion has clashed with the imperatives of stability, containment, or a climate conducive to powerful business interests, democracy has almost always been given short shrift. ${ }^{52}$

Nevertheless, the insistence on the absolute harmony of all good things in much US public rhetoric is by no means accidental or careless: it is vital to the justification of the entire project. To the extent that material interests figure at all in publicly offered justifications for new empire, policy makers typically insist that US interests and US ideals are congruent, that US ideals in turn are universal ideals, ${ }^{53}$ and therefore, that there is an almost perfect correspondence between US interests and universal ideals. These inarticulate premises allow US National Security Adviser Condoleezza Rice to proclaim: 'America's pursuit of the national interest will create conditions that promote freedom, markets and peace ... the triumph of these values is most assuredly easier when the international balance of power favours those who believe in them. . . America's military power must be secure because the US is the only guarantor of global peace and stability' ${ }^{54}$ Ignatieff does nothing to interrogate these clichés of US foreign policy. Instead he plays along by grafting his human rights agenda on to what he knows to be the less altruistic game plan of the current US administration.

50. Ignatieff, 'Why Are We In Iraq?', 71.

51. Or it might conclude that recent decrees passed by the US-UK Coalition Provisional Authority, permitting foreigners to own up to $100 \%$ of all sectors except natural resources and imposing a flat tax rate of $15 \%$, are not conducive to the imperatives of reconstruction and development. See Naomi Klein, 'Bring Halliburton Home', The Nation (November 6, 2003).

52. Whitehead, 'The Imposition of Democracy', 358; Steven W. Hook, 'Inconsistent U.S. Efforts to Promote Democracy Abroad', in Exporting Democracy: Rhetoric vs. Reality, ed. Peter J. Schraeder (Boulder: Lynne Rienner Publishers, 2002), 121-123.

53. For a devastating critique of this tendency, see E. H. Carr, The Twenty Years' Crisis 1919-1939 (London: Macmillan, 1949), 87.

54. Condoleezza Rice, 'Promoting the National Interest', Foreign Affairs 79, no. 1 (2000): $47,49,50$. 
Ignatieff advises liberals to support the war on Iraq because he sees it as 'bound to improve the human rights of Iraqis'. ${ }^{55}$ Any misgivings we might have about neo-conservative motivations for intervention are assuaged with the argument that such concerns seem to value good intentions more than good consequences. ${ }^{56}$ This attempt to justify the intervention through a strictly consequentialist lens is untenable. For one thing, Ignatieff recognises the need to acknowledge the antiimperialist norms of the postwar era. Towards this end, he is keen to distinguish the new US empire from the empires of old-but in doing so, he can only point to good intentions: 'The twenty-first century imperium is a new invention in the annals of political science, an empire lite, a global hegemony whose grace notes are free markets, human rights and democracy'. ${ }^{57}$ By Ignatieff's own admission, vital elements of these 'grace notes' are missing in the neo-con decision-making calculus-so how different really is new empire from old?

Further, the success of the intervention (from both neo-con and liberal perspectives) seems to rest crucially on good intentions. ${ }^{58}$ One important insight of Ferguson's Empire is that without the collaboration of indigenous elites, Britain would not have had the human or financial resources to 'rule' a quarter of the world's population. ${ }^{59}$ US empire has learnt this lesson well and also depends significantly on the cooperation and assistance of native elites. ${ }^{60}$ There will never be a shortage of opportunistic collaborators (native elites whose motivation for collaboration derives primarily from the personal material gains on offer, rather than any sense of mission or duty to resuscitate their failing states). But opportunistic collaborators are Frankenstein's monsters: they have precipitated precisely those problems that new empire has been called upon to deal with. Max Boot seems unconcerned by this possibility, writing: 'Once we have deposed Saddam, we can impose an American-led, international regency in Baghdad, to go along with the one in Kabul. With American seriousness and credibility thus restored, we will enjoy fruitful cooperation from the region's many opportunists, who will show a newfound eagerness to be helpful in our larger task of

55. Ignatieff, 'Why Are We in Iraq?', 43.

56. Ibid.

57. Ignatieff, 'The Burden', 24.

58. Ignatieff does finally come around to this position, though for entirely different reasons. See, 'The Way We Live Now'.

59. Ferguson, Empire, 188, 189. See also Ferguson, 'Empire: The Rise and Demise of the British World Order and Lessons for Global Power'.

60. Bacevich argues that the US has found functional equivalents for both gunboats and gurkhas-key tools of British imperial expansion and control. See, American Empire, ch. 6. See also Johnson, The Sorrows of Empire, ch. 5. 
rolling up the international terror network that threatens us $^{\prime}{ }^{61}$ Boot's vision reads like a recipe for more blowback. Even from a self-regarding perspective it should be obvious that opportunistic collaborators are notoriously unreliable, their cooperation ebbing and flowing in proportion to the patronage they receive. From an other-regarding perspective, opportunistic collaborators are hardly likely to run the sorts of governments that respect the human rights of their peoples. Thus, opportunistic collaborators are unlikely to facilitate the success of the intervention (except in the very short-term), whether 'success' is defined as security for the metropolis or the periphery.

What sorts of collaborators new empire needs and attracts will depend crucially on the motives of the new imperialists. If the neoimperialist project is animated even partly by a desire to bring human rights and democracy to dangerous and unstable peripheral zones, it will need principled native collaborators-individuals whose primary allegiance is to securing good governance for their peoples. 'Principled collaboration' may sound like a contradiction in terms, but it captures better than anything else the dilemma in which native elites ${ }^{62}$ with any commitment to good governance are likely to find themselves. 'Collaboration' has the loathsome connotation of 'traitorous cooperation with the enemy', but it can also be used in the value-neutral sense of participation in a joint endeavour. ${ }^{63}$ What connotation it carries depends very much on the agenda of the (more powerful) external actor with whom one is called upon to collaborate-in other words, on the intentions and motives of the intervener. The legitimacy of native elites in the eyes of their people will in turn be determined by the nature of collaboration (mutually beneficial partnership or traitorous cooperation?) that they are perceived to be engaging in.

It is only within such a framework that we can understand such unexpected events as the decision of Siham Hattab not to stand in council

61. Boot, 'The Case for American Empire'.

62. The very use of the term 'elite' is problematic from the perspective of a radical commitment to democracy. I use the term loosely, to refer to people in pre-intervention positions of authority. Whether or not that authority is legitimate (in the eyes of insiders and outsiders) poses further problematic issues that I cannot adequately deal with here. For the argument that the genius and tragedy of US democracy promotion efforts has been that they have always tried to introduce political innovations while working with, and through, the existing socio-economic elite, see Tony Smith, America's Mission: The United States and the Worldwide Struggle for Democracy in the Twentieth Century (Princeton: Princeton University Press, 1994), 18.

63. Oxford English Dictionary Online (2004). 
elections in Baghdad. As an educated young woman from a conservative Shia family, a lecturer in English literature by profession, representing one of the most deprived districts of Baghdad, this 'rising star of Iraqi politics' is potentially a model collaborator in every sense of the word (or at least from the perspective of the Coalition Provisional Authority). Yet her reluctance to declare her candidature in a high-profile election stems from a fundamental ambivalence over the ethics of cooperation with the CPA. ${ }^{64}$ Principled collaborators are unlikely to step forward (or to enjoy any legitimacy, if they do) if the US intervention is perceived to be primarily about consolidating its dominance in the region. (This, as Ignatieff informs us, is principally what the neo-cons had in mind.) Indeed, I would go so far as to say that in this post-imperial age in which there are far too many politicised people on earth today for any nation readily to accept the finality of America's historical mission to lead the world', ${ }^{\prime 6}$ principled collaborators are unlikely to step forward at all, if they perceive that what they are collaborating with is empire. ${ }^{66}$

\section{The Immorality of Empire}

Even shorn of its exploitative and racist historical baggage, 'empire' as a form of political organisation remains deeply objectionable because it is premised on the complete denial of agency of those ruled without representation. This normative objection applies to all exercises of imperial power wherever they occur-not merely to modern European 'saltwater' empires. In this context, Martin Shaw is right to draw our attention to the 'quasi-imperial' character of political relations in much of the non-Western world. ${ }^{67}$ Even in a democratic polity such as India, to the extent that the state is engaged in repressing legitimate selfdetermination struggles or in a civilising mission vis-à-vis its tribal population for example, the imperial quality of political life is palpable. ${ }^{68}$ Shaw is much less convincing when he goes on to argue, first, that the West has become post-imperial, and second, that 'the reassertion of post-

64. Rory McCarthy, 'Doubts hold back rising star of Iraqi politics', The Guardian (February 10, 2004).

65. Said, Culture and Imperialism, 348.

66. See also Purdy, 'Liberal Empire', 44: 'The universality and power of nationalism as a political motivation is perhaps the most salient single difference between the circumstances of previous imperial powers and the situation of the US today'.

67. Shaw, 'Post-Imperial and Quasi-Imperial', 333.

68. In permitting the resumption of construction of the Sardar Sarovar dam, notwithstanding its displacement of tens of thousands of tribal people, the Supreme Court of India in Narmada Bachao Andolan v. Union of India, (2000) 10 SCC 664, was eerily reminiscent of a colonial civil servant or proselytising 
imperial Western power ... has been in turn a response to crises in the quasi-imperial states of the non-West'. ${ }^{69}$ Again, we are presented with the image of the West as benign, public-spirited fire-fighter, rushing to the rescue of victims in messy, quasi-imperial non-Western states.

This imagery is odd because most of the changes that Shaw describes in the way Western power is exercised, suggest that it has become post-imperial-if at all-in its intra-bloc relations (i.e. within the developed capitalist world comprising the US, Europe and East Asia). It is here that elements of hierarchy have been mitigated, not least by greater economic parity, but also through more extensive and meaningful consultation and partnership in such fora as the G8, NATO, etc. But while the West may have become post-imperial in its internal relations, its frequent assertions of power in the non-Western world cannot be considered post-imperial unless we adopt the unwarranted assumption that such intervention occurs purely for altruistic reasons and always at the behest of the putative beneficiaries. If Western intervention in the non-Western world continues to be imperial, then Shaw's suggestion that this is a justifiable response to crises in the quasiimperial states of the non-West is deeply problematic. As I have argued above, many of these crises (arbitrary boundaries and self-determination struggles, exploitive class structures and tyrannical elites) are a hangover from older periods of empire. To argue that they can only be dealt with by a renewed exercise of Western imperial power, risks perpetuating a vicious cycle.

The normative objection to empire as a form of rule without representation applies even if, as many have argued, empires supply public goods. ${ }^{70}$ From the perspective of the smaller actors in the system, even in a best-case scenario where genuine public goods were provided free of charge, the provision of goods that the hegemon would have produced anyway (because it is in its private interest to do so) whether or

missionary: 'The displacement of the tribals ... would not per se result in the violation of their fundamental or other rights.... At the rehabilitation sites they will have more and better amenities than which they enjoyed in their tribal hamlets. The gradual assimilation in the mainstream of the society will lead to betterment and progress'. (Justice Kirpal)

69. Shaw, 'Post-Imperial and Quasi-Imperial', 331, 332, 335.

70. There is a vast amount of literature justifying hierarchy from a public goods argument. For a brilliantly argued liberal perspective see Lea Brilmayer, American Hegemony: Political Morality in a One-Superpower World (New Haven: Yale University press, 1994), especially ch. 6. For a sampling of hegemonic stability theory see Charles Kindleberger, 'Dominance and Leadership in the International Economy: Exploitation, Public Goods and Free Rides', International Studies Quarterly 25, no. 2 (1981): 242-254; Charles Kindleberger, 'Hierarchy 
not these smaller actors existed, essentially renders those actors irrelevant. It carries all the offensive paternalistic connotations of being treated as a ward of the state, lacking in mental (or physical) capacity, and therefore being told what is 'good for you' with no meaningful autonomy or participation in your own governance. ${ }^{71}$ But perhaps this argument is unappealing to those not of a liberal persuasion. So let us suppose for the sake of argument that empire would not be morally problematic if it provided genuine public goods. In that case, the relevant question becomes whether this (US) empire at this point in time is providing the public goods that it claims to. There has been a great deal of careless piggybacking on hegemonic stability theory (HST) in recent work on empire, ${ }^{72}$ without more careful consideration of Duncan Snidal's warning that 'the range of the theory is limited to very special conditions' and that 'while some international issue-areas may possibly meet these conditions, they do so far less frequently than the wide application of the theory might suggest ${ }^{\prime} .{ }^{73}$ Although a rigorous analysis of this problem is beyond the scope of this article, I want to outline briefly the contours of a possible counter-response to the public goods argument.

If security is allegedly the principal public good supplied by the US empire ${ }^{74}$ the first question to ask is whether security is a public good. Public goods are defined as non-excludable (it is impossible to prevent non-contributors from enjoying the good) and joint (a number of actors are able simultaneously to consume the same produced unit of the good

Versus Inertial Cooperation', International Organisation 40, no. 4 (1986): 841-847; Robert O. Keohane, 'The Theory of Hegemonic Stability and Changes in International Economic Regimes, 1967-1977', in Change in the International System, eds. Ole R. Holsti, Randolph M. Siverson \& Alexander L. George (Boulder: Westview Press, 1980), 131-162; See also Joseph Nye, The Paradox of American Power: Why the World's Only Superpower Can't go it Alone (Oxford: Oxford University Press, 2002), 142-147.

71. If this sounds like I am anthropomorphising the state, for an account of the familial, religious and other metaphors on which hegemonic stability theory intuitively relies for its persuasiveness, see Isabelle Grunberg, 'Exploring the "Myth" of Hegemonic Stability', International Organisation 44, no. 4 (1990): 431477 .

72. Cox, 'The Empire's Back in Town', 26; Charles S. Maier, 'An American Empire?', Harvard Magazine 105, no. 2 (2002): 29; Eyal Benvenisti, 'The US and the Use of Force: Double Edged Hegemony and the Management of Global Emergencies', http://users.ox.ac.uk/ magd1538/benvenisti.pdf (who, however, does not use the term 'empire').

73. Duncan Snidal, 'The Limits of Hegemonic Stability Theory', International Organisation 39, no. 4 (1985): 579.

74. Maier, 'An American Empire?', 29; Benvenisti, 'The US and the Use of Force', 7. 
without detracting from each other's enjoyment). While some idealised version of 'world peace' might satisfy this definition, security as currently envisaged by the US does not. First, security is not nonexcludable-as Snidal points out, alliances and defence pacts are premised on providing peace and security benefits to some but not others, ${ }^{75}$ Bruce Russett argues that even for 'peace' by dominance, one can choose boundaries to the areas one pacifies, excluding strategically insignificant or uncooperative governments from one's defensive or deterrent umbrella. ${ }^{76}$ The US National Security Strategy speaks of 'prevent[ing] our enemies from threatening us, our allies, and our friends with WMD'. ${ }^{77}$ Further, the concept of the 'security dilemma' suggests that making some secure requires rendering others insecure, thereby undermining the 'jointness' of security. As many have emphasised, this is true even of (apparently) wholly defensive measures such as Ballistic Missile Defence $^{78}$ (which is precisely why they have evoked such a hostile reaction from China and others). If the criteria of nonexcludability and joint-ness are not satisfied, then security cannot be considered a public good. ${ }^{79}$

Second, if the means by which the US provides security rouse hostility and resentment in much of the non-Western world and invite retaliation on a worldwide scale-against not only the US itself but also its friends, allies, collaborators and anyone in the way-then there are very sound reasons for doubting whether US-imposed 'security' is a public good. Johnson writes that 'world politics in the twenty-first century will in all likelihood be driven primarily by blowback from the second half of the twentieth century - that is, from the unintended [foreseeable?] consequences of the Cold War and the crucial American decision to maintain a Cold War posture in a post-Cold War world'.$^{80}$ To this might be added the obvious codicil that world politics for a long time to come will be driven by blowback from the US-led 'war on terror'. If this is true, then the US may be said to be producing public 'bads' both for itself and others. One way of reconciling my scepticism of 'public-ness' with my

75. Snidal, 'The Limits of Hegemonic Stability Theory', 596.

76. Bruce Russett, 'The Mysterious Case of Vanishing Hegemony; or, is Mark Twain Really Dead?', International Organisation 39, no. 2 (1985): 224-225.

77. The National Security Strategy of the United States of America (Washington, DC: The White House, September 2002), 13 (emphasis mine).

78. Johnson, The Sorrows of Empire, 84-85.

79. For an argument that free trade is not a public good because it exhibits the properties of excludability and rivalry see John A. C. Conybeare, 'Public Goods, Prisoner's Dilemma and the International Political Economy', International Studies Quarterly 28, no. 1 (1984): 5-22.

80. Johnson, Blowback, 237-238. 
scepticism of 'good-ness' is to suggest that while the goods (if any) of US security-imposition are privatised, the bads are well and truly shared (or worse, externalised). This is another way of telling the story of the Cold War: pacification in the core and proxy war in the periphery.

Third, proponents of HST argue that the theory is legitimised by the implicit quid pro quo on which it rests: in return for foregoing representation in decisions concerning what public goods are to be produced and how, lesser actors are able to free-ride (i.e. consume public goods without paying for them). When asked why a rational hegemon would permit free-riding, it is argued that the very nature of the goods supplied (i.e. their non-excludability and joint-ness) makes it impossible for the hegemon to tax their use. But having seen that the goods are often private, or only imperfectly public at best, HST's built-in assumption of benevolence turns out to be unwarranted or exaggerated. Further, unless hegemony is defined purely in absolute and not at all in relative terms, the hegemon is likely to be much more powerful than other actors in the system. Even if the goods supplied are perfectly public, this opens up the possibility that the hegemon will extract payment through crosslinkage of issue-areas (i.e. I cannot extract payment for perfectly public good X, but if you do not pay nevertheless, I will withhold imperfectly public good Y). Thus, regardless of whether the hegemon is able to enforce exclusion, it may be capable of coercing others into paying for the goods. ${ }^{81}$ As a rational actor seeking to further its own self-interest, the hegemon can be expected to use every available means to extract payment for the goods it provides. ${ }^{82}$ If public goods are not free, as the more benevolent variants of HST suggest, then this is a case of taxation without representation-an injustice even most Americans ought to be able to empathise with.

Fourth, even in the case of genuine public goods that are provided free of charge, it is by no means self-evident that free-riding works to the detriment of the hegemon. A number of writers have commented on the extent to which the hegemon actively welcomes and seeks to perpetuate the situation of free-riding, as a means of exacerbating the dependence of its allies and enhancing its leverage vis-à-vis them. ${ }^{83}$ Hegemonic

81. Snidal, 'The Limits of Hegemonic Stability Theory', 592-593.

82. Grunberg, 'Exploring the "Myth" of Hegemonic Stability', 441. For an analogous view on free trade also see Conybeare, 'Public Goods, Prisoner's Dilemma and the International Political Economy', 11, 13. But for a view that the need to maintain continued hegemony will exercise a check on the hegemon's tendency to behave exploitatively see Bruce Cronin, 'The Paradox of Hegemony: America's Ambiguous Relationship with the United Nations', European Journal of International Relations 7, no. 1 (2001): 103-130.

83. See for example Prestowitz, Rogue Nation, 166, 242. 
stability theorists are therefore misleading when they characterise freeriding as an unqualified benefit to lesser actors. Given the role that freeriding plays in providing a moral prop for the theory, a view that underscores the ambiguity of the gains from free-riding for smaller actors makes the entire edifice of HST look morally suspect.

Whatever the merits of the imperial imposition of public goods, we ought not to be precluded from enquiring into whether this is the best or only means of providing such goods (i.e. empire may be a sufficient condition for the provision of public goods, but is it a necessary one?). Disturbingly, by proclaiming its intention to dissuade anyone from 'surpassing, or equalling, the power of the United States', the US NSS does just this. ${ }^{84}$ By seeking to perpetuate the dominance of the US and the massive power deficit that already exists between itself and the rest of the world, the NSS effectively slams the door shut on any discussion of more equitable means of providing global public goods such as security. A great deal more needs to be said to demonstrate the moral bankruptcy of theories advocating the imperial provision of public goods. At the very least, I hope to have cast reasonable doubt on the oftrepeated assertion that this empire is legitimised by the public goods that it provides, of which global security is said to be the foremost.

To conclude, writing about events that are unfolding contemporaneously invites the risk of being overtaken by developments on the ground and proved disastrously wrong. Nevertheless, I believe my critique of empire will remain unaffected by the vicissitudes of US political fortunes in Iraq, because it points to the essential immorality and impracticality of empire in a post-imperial age. Ignatieff has not demonstrated that empire, however heavy, can accomplish the task of nation-building. His defensive case for empire is specious because it overlooks the extent to which the circumstances of state-failure that allegedly justify new empire are themselves a consequence of older empire, and indeed older US empire. His (earlier) strictly consequentialist attempt to justify the 2003 Iraq war is blind to the fact that 'success' depends crucially on the cooperation of Iraqiscooperation that is unlikely to be forthcoming if they are suspicious of US intentions. His (current) acceptance of the importance of intentions is welcome, but does nothing to address concerns about the likelihood and nature of local collaboration. Whether one describes what is going on in the world today as 'empire' or uses the more technocratic euphemism

84. The National Security Strategy, 30. See also Thomas Donnelly, 'Rebuilding America's Defences: Strategy, Forces and Resources for a New Century', A Report of The Project for the New American Century (September 2000), (i). 
'hegemony', ${ }^{85}$ consent of the governed seems to be vital to the success of the project. Part of what it means to live in a post-imperial age is that the abhorrence of empire is too visceral-too deep a part of political consciousness, at least in the Third World-for that consent to be freely given. If the US experiment in Iraq is to be successful, it will have to be so different from the empires of old as not to look like-more importantly, not to be-empire anymore.

Rahul Rao is reading for a D.Phil. in International Relations at Balliol College, University of Oxford

85. For arguments that the US is appropriately described as an empire, see Cox, 'The Empire's Back in Town', 14-22; Niall Ferguson, 'Hegemony or Empire?', Foreign Affairs (September/October 2003); Vijay Prashad, 'Casual Imperialism', People's Weekly World (August 16, 2003); Geir Lundestad, The American 'Empire' (Oxford: Oxford University Press, 1992), 37-39. For arguments that 'hegemony' is the more appropriate term see Michael Walzer, 'Is There an American Empire?', Dissent (Fall 2003). See also Martin Walker, 'America's Virtual Empire', World Policy Journal 19, no. 2 (2002): 20, who writes that although 'empire' is a useful metaphor, American empire is a new beast, the likes of which has never been seen before. 